\title{
Hormonal risk factors and invasive epithelial ovarian cancer risk by parity
}

\author{
C Bodelon ${ }^{\star}, 1$, N Wentzensen ${ }^{1}$, S J Schonfeld ${ }^{1,2}$, K Visvanathan ${ }^{3,4}$, P Hartge ${ }^{1}$, Y Park ${ }^{1}$ and R M Pfeiffer ${ }^{1}$ \\ ${ }^{1}$ Division of Cancer Epidemiology and Genetics, National Cancer Institute, NIH, DHHS, Rockville, MD, USA; ${ }^{2}$ Section of \\ Environment and Radiation, International Agency for Research of Cancer, Lyon, France; ${ }^{3}$ Department of Epidemiology, \\ Bloomberg School of Public Health, Johns Hopkins University, Baltimore, MD, USA and ${ }^{4}$ Department of Oncology, School of \\ Medicine, Johns Hopkins University, Baltimore, MD, USA
}

Background: Recent studies have suggested that several ovarian cancer risk factors differ by parity status, but these findings have not been confirmed. We evaluated whether known risk factors of ovarian cancer differ between nulliparous and parous women using data from two large prospective cohorts.

Methods: Data from the National Institutes of Health-AARP Diet and Health Study and the Prostate, Lung, Colorectal and Ovarian Cancer Screening Trial were combined for this analysis. Cox regression models were used to estimate associations with ovarian cancer risk. Risk heterogeneity by parity status was assessed using likelihood-ratio tests.

Results: Among the 125437 women included in the analysis, there were $16589(13 \%)$ nulliparous women and 108848 (87\%) parous women. Of the 623 women diagnosed with invasive epithelial ovarian cancer, $102(16 \%)$ were nulliparous and $521(84 \%)$ were parous. While parity reduced ovarian cancer risk, no differences were found for other risk factors by parity. Among ever users of hormone therapy, body mass index suggestively increased the risk of ovarian cancer by 1.5 -fold in nulliparous but not parous women $(P$-heterogeneity $=0.08)$.

Conclusion: While nulliparous women have higher ovarian cancer risk than parous women, our findings suggest that the relative effects of most other risk factors do not differ by parity.

Parity is a well-established protective factor for ovarian cancer (Hankinson and Danforth, 2006). In a collaborative analysis of 12 case-control studies, women with at least one full-term pregnancy were at a significantly lower risk compared with nulliparous women (odds ratio $(\mathrm{OR})=0.60,95 \%$ confidence interval (CI): $0.47-0.76$ ), and each additional full-term pregnancy lowered the risk further $\left(P_{\text {trend }}<0.001\right)$ (Whittemore et al, 1992). Similar results have been found in cohort studies (Adami et al, 1994).

Recently, it has been suggested that associations between several ovarian cancer risk factors, such as body mass index (BMI) or the use of oral contraceptives (OCs), may differ by parity status (Ness et al, 2001; Greer et al, 2006). Greer et al (2006) found that a high BMI significantly increased the risk of ovarian cancer in nulliparous women $(\mathrm{OR}=2.53,95 \% \mathrm{CI}$ : $1.39-4.61$ comparing the top to the bottom quartile of the BMI distribution), but not in parous women $(\mathrm{OR}=0.96,95 \% \mathrm{CI}$ : $0.70-1.31$ comparing the top to the bottom quartile of the BMI distribution). In the same population, use of oral contraceptive (OC) did not reduce the risk of ovarian cancer in nulliparous women $(\mathrm{OR}=0.9,95 \% \mathrm{CI}$ : $0.5-1.7)$ but was suggestively associated with a reduced risk in parous women $(\mathrm{OR}=0.6,95 \% \mathrm{CI}$ : $0.3-1.1$ in women with one birth; $\mathrm{OR}=0.6 ; 95 \% \mathrm{CI}: 0.4-1.0$ in women with two births; $\mathrm{OR}=0.7,95 \% \mathrm{CI}: 0.5-1.0$ in women with three or more births) (Ness et al, 2001). The authors did not explore whether other ovarian cancer risk factors differ by parity. These results were based on a retrospective sample, which could have affected their BMI results. In addition, the study population included pre- and post-menopausal women, with $40 \%$ of the cases being younger than 50 years of age (Ness et al, 2000), and associations between 
BMI or OC use and ovarian cancer risk may differ between preand post-menopausal women (Tung et al, 2005; Moorman et al, 2008; Olsen et al, 2013). A further limitation of the studies by Ness et al $(2000,2001)$ is the inclusion of borderline and invasive ovarian cancer cases. It has been suggested that BMI and OC use could be more strongly associated with borderline tumours (Modugno et al, 2001; Collaborative Group on Epidemiological Studies of Ovarian Cancer, 2012; Olsen et al, 2013). Therefore, these results need confirmation in large, prospective data sets, with information on menopausal status and use of hormone therapy (HT) among postmenopausal women. A different study reported an interaction effect between family history and parity on the risk of ovarian cancer (Vachon et al, 2002).

To our knowledge, a systematic investigation of whether parity modifies the association between other ovarian cancer risk factors and ovarian cancer risk has not been done. Understanding the interplay between parity and other ovarian cancer risk factors could help to better understand the biological mechanism in the development of ovarian cancer. In the current analyses, we, therefore, evaluated whether the associations of several known risk factors for ovarian cancer differ between nulliparous and parous postmenopausal women using combined data from two large prospective cohorts.

\section{MATERIALS AND METHODS}

Study population. Data from two prospective cohorts, the National Institutes of Health-AARP Diet and Health Study (NIH-AARP) (Schatzkin et al, 2001) and the Prostate, Lung, Colorectal, and Ovarian Cancer Screening Trial (PLCO) (Prorok et al, 2000) were combined for this analysis (Figure 1). Both studies have been previously described (Prorok et al, 2000; Schatzkin et al,
2001). Briefly, the NIH-AARP study was established in 1995-1996 when over 500000 AARP members, aged 50-71 in six states (California, Florida, Louisiana, New Jersey, North Carolina and Pennsylvania) and two metropolitan areas (Atlanta, GA, and Detroit, MI) satisfactorily completed a baseline questionnaire (Schatzkin et al, 2001). A second questionnaire was sent in 19961997 to obtain additional risk factor information, including family history of breast and/or ovarian cancer. Information from both questionnaires was used in this analysis (baseline questionnaire collected in 1995-1996 and second questionnaire collected in 1996-1997). The last follow-up date for this study was 31 December 2006. The NIH-AARP study was approved by the Special Studies Institutional Review Board of the National Cancer Institute. The PLCO study is a multi-centre, randomised trial designed to evaluate screening modalities for prostate, lung, colon, and ovarian cancers (Prorok et al, 2000). Participants were recruited between 1992 and 2001 and they were followed for up to 13 years. For this analysis, the last follow-up time for the PLCO was 31 December, 2006. At enrolment, women aged 55-74 years old, without a history of ovarian cancer completed a baseline questionnaire. Exposure data from this questionnaire, collected from 1992 to 2001, was used in the analysis. Only information from women in the screening arm of the PLCO study was available when these analyses were conducted. Informed consent for the PLCO was obtained from all women and each screening centre obtained approval by the local institutional review boards. In both studies, participants completed self-administered questionnaires or telephone-based interviews with information regarding demographic and lifestyle characteristics, as well as reproductive and medical history. Data from the both studies were harmonised into a single data set (Supplementary Note). Analyses were restricted to women who reported at age at menopause at the beginning of either study.

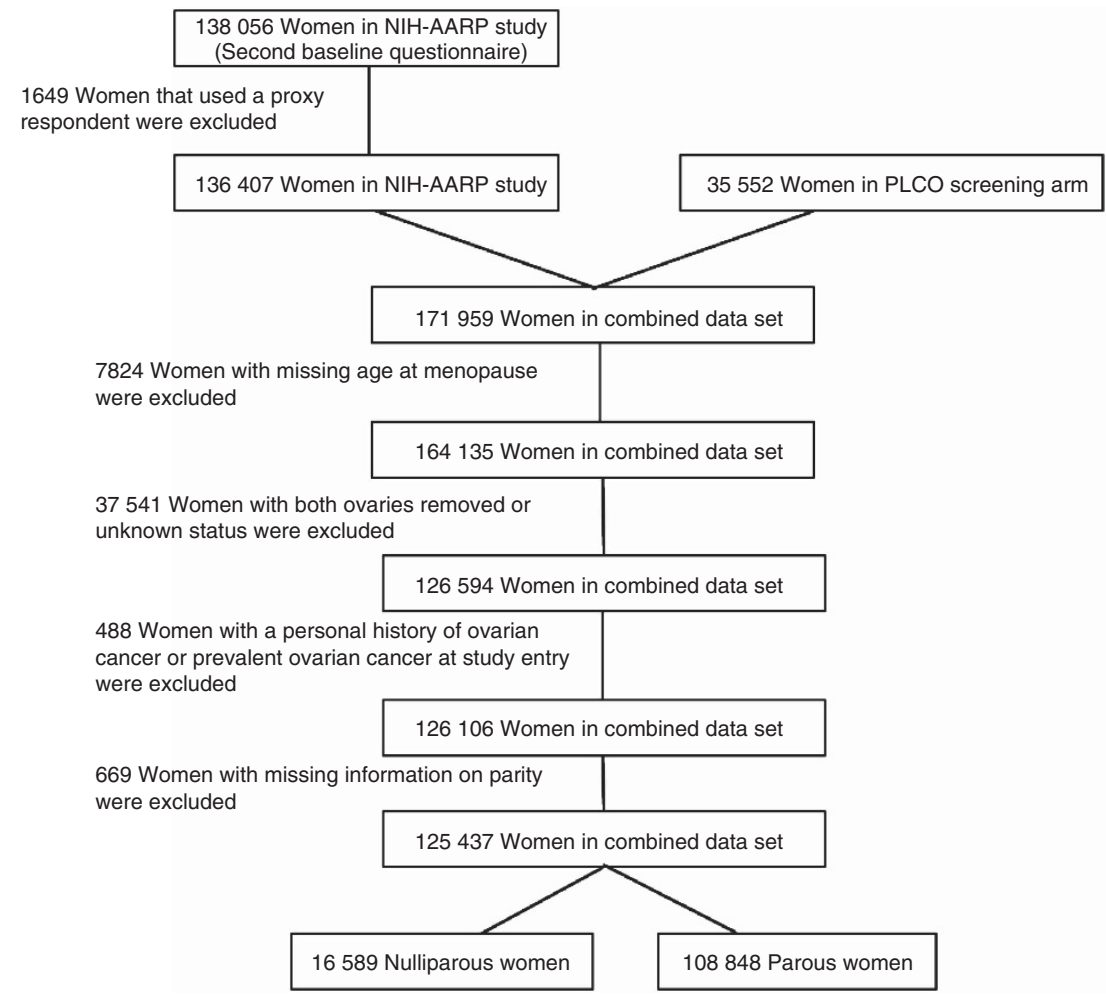

Figure 1. Flow diagram of criteria and numbers of study participants included in the analysis. Of the 125437 women included in the analysis, 30197 (24.1\%) came from the PLCO study and 95240 (75.1\%) came from the NIH-AARP study. Reflecting these proportions, of the 623 ovarian cases, 153 (24.6\%) came from the PLCO study and 470 (75.4\%) from the NIH-AARP study. 
Outcome ascertainment. National Institutes of Health-AARP participants were followed through the US Postal Service national database for address changes and cancers were ascertained by linkage to state cancer registries in the original recruitment areas plus three catchment areas that were common states of relocation (Arizona, Nevada, and Texas) (Schatzkin et al, 2001). Vital status was updated from the US Social Security Administration Death Master File and the National Death Index Plus (Schatzkin et al, 2001). The completeness of case ascertainment has been previously reported to have a minimum sensitivity of $\sim 90 \%$ and specificity of $99.5 \%$ compared with identification of cases by cancer registries (Michaud et al, 2005). Follow-up in the PLCO was conducted from annual study update forms completed by participants or a proxy and subsequently confirmed from medical records, death certificates, and cancer registries (Prorok et al, 2000). Subjects who did not return the questionnaire were contacted by repeat mailing or telephone to improve completeness of end point ascertainment.

The outcome of interest for this analysis was primary invasive epithelial ovarian cancer. Using the International Classification of Diseases for Oncology, 3rd edition, (ICD-O-3) coding system (Fritz et al, 2000), these were cases with C56.9 site codes and epithelial morphology (serous: 8441, 8460, 8461; endometrioid: 8380, 8381, 8560, 8570; mucinous: $8470,8471,8480,8481$; clear cell: 8310,8313 ; and other epithelial: $8010,8020,8021,8050,8070$, $8120,8140,8240,8246,8255,8260,8323,8440,8450,8490,8562)$.

Statistical methods. Cox regression models were used to compute hazard ratios (HRs) and 95\% CIs as measures of association between risk factors and incidence of ovarian cancer. Follow-up started at the age at the time of the second questionnaire for women in the NIH-AARP study or the age at the baseline questionnaire for women in the PLCO and ended at the age of diagnosis of invasive epithelial ovarian cancer or censoring at the age of death, loss of follow-up, or 31 December 2006, whichever occurred first. The baseline hazard function was stratified by study (PLCO vs AARP) in all models.

Women who reported at least one live birth or provided an age at first birth were classified as parous and those who reported no age at first birth and no live births were considered nulliparous, similar to Schonfeld et al (2011). Subjects were excluded from the analysis if they did not report age at menopause at the beginning of the study, had a bilateral oophorectomy or unknown ovarian surgery status, had a personal history of ovarian cancer, prevalent ovarian cancer at study enrolment, had missing information on parity, or if questionnaire information was obtained via proxy respondents (see Figure 1).

Analyses were done separately for nulliparous and parous women from both cohorts combined. Analyses for nulliparous women were adjusted for BMI at study entry (continuous), duration of use of OC (never or $\langle 1 / 1-9 / \geqslant 10$ years), duration of use of HT (never/ $<10 / \geqslant 10$ years), first degree family history of breast and/or ovarian cancer (no/yes/missing). Analyses for parous women were adjusted for the same variables as nulliparous women and in addition for the number of live births in categories $(1 / 2 / 3-4 / \geqslant 5)$. When models were additionally adjusted for education, marriage, age at menopause, age at menarche or hysterectomy status results did not significantly changed. To assess differences in effects by parity status, we compared a Cox model that combined the data of the nulliparous and parous women and was adjusted for all the above factors and parity (no/yes) to a similar model with an additional interaction term between parity and the risk factor of interest modelled as a continuous variable. Significance of the interaction term was determined by a likelihood-ratio test.

The number of lifetime ovulatory cycles (LOCs) was computed using the model by Cramer et al (1995) that estimates LOC based on the age at menopause, age at menarche, time being pregnant, duration of OC, and the average cycle length. We assumed that the average cycle length of all participants was 28 days. Estimated LOCs from this model result in similar estimates as to those from other published models (George, 2011). Quartiles of LOCs were defined based on their distribution in the entire study population.

The proportional hazard assumption was tested based on the slope of the Schoenfeld's residuals (Grambsch and Therneau, 1994). All statistical tests were two-sided and $P$-values $<0.05$ were considered statistical significant. Analyses were performed by using STATA, version 10.1, software (StataCorp LP, College Station, TX, USA).

\section{RESULTS}

A total of 125437 women were included in the analysis, with 16589 (13\%) nulliparous women and 108848 (87\%) women who reported having had at least one live birth. During the study period, 623 women were diagnosed with invasive epithelial ovarian cancer; 102 (16\%) were nulliparous and 521 (84\%) reported having had at least one live birth. The median follow-up time for women in this analysis was 10.55 years (interquartile range: $10.52,10.80$ years).

Characteristics of study participants according to parity status are shown in Table 1. Nulliparous women were younger, had higher education, were more likely to never have been married and were less likely to have used OCs, HT or to have undergone hysterectomy or tubal ligation compared with parous women. Parous women were at a reduced risk of ovarian cancer compared with nulliparous women ( $\mathrm{HR}=0.79,95 \% \mathrm{CI}$ : 0.63 , 0.98 ) (Table 2), with stronger reduction of the risk with more births $\left(P_{\text {trend }}<0.001\right)$.

There were no clear differences in the risk estimates for hormonal factors and other characteristics between parous and nulliparous women (Table 3). The use of OC reduced the risk of ovarian cancer similarly in both nulliparous and parous women $(P$-heterogeneity $=0.98)$. Similar results were observed when analyses were restricted to nulliparous women who reported ever having been married (married, widowed, divorced, or separated) or living as married. Long duration of use of HT increased the risk in both groups of women (Table 3). Compared with women who had an estimated number of 470 or more LOCs, both nulliparous and parous women with an estimated number of $<330$ LOCs had lower risk of ovarian cancer. First degree family history of breast and/or ovarian cancer increased the risk of ovarian cancer in both groups of women $(\mathrm{HR}=1.37,95 \% \mathrm{CI}$ : $0.81,2.34$ in nulliparous women; $\mathrm{HR}=1.21,95 \% \mathrm{CI}: 0.97,1.51$ in parous women) $(P$-heterogeneity $=0.60)$. BMI was associated with a non-statistically significant increased risk of ovarian cancer in nulliparous women (HR $=1.36,95 \% \mathrm{CI}: 0.79,2.36$, comparing $25-29.9 \mathrm{~kg} \mathrm{~m}^{-2}$ to $<25 \mathrm{~kg} \mathrm{~m}^{-2}$; $\mathrm{HR}=1.48,95 \%$ CI: $0.61,3.58$ comparing $30 \mathrm{~kg} \mathrm{~m}^{-2}$ or more to $<25 \mathrm{~kg} / \mathrm{m}^{2}$ ), but was unrelated to ovarian cancer risk in parous women $(\mathrm{HR}=0.84,95 \% \mathrm{CI}: 0.66,1.07$, comparing $25-29.9 \mathrm{~kg} \mathrm{~m}^{-2}$ with $<25 \mathrm{~kg} / \mathrm{m}^{-2} ; \mathrm{HR}=1.03,95 \%$ CI: $0.69,1.53$ comparing $30 \mathrm{~kg} \mathrm{~m}^{-2}$ or more with $<25 \mathrm{~kg} \mathrm{~m}^{-2}$ ) $(P$-heterogeneity $=0.15)$. BMI was still associated with a nonsignificant increased ovarian cancer risk among ever married nulliparous women although the association was attenuated $\left(\mathrm{HR}=1.33,95 \% \mathrm{CI}: 0.51,3.47\right.$ comparing $30 \mathrm{~kg} \mathrm{~m}^{-2}$ or more to $\left.<25 \mathrm{~kg} \mathrm{~m}^{-2}\right) \quad(P$-heterogeneity $=0.19)$. Compared with never smokers, nulliparous women who were current smokers were at an increased risk of ovarian cancer $(\mathrm{HR}=1.40,95 \% \mathrm{CI}: 0.78,2.49)$, but the increased was not seen for parous women who were current smokers $(\mathrm{HR}=0.76,95 \% \mathrm{CI}: 0.55,1.05)(P$-heterogeneity $=0.10)$. Similar results were obtained when analyses were further adjusted by education level. 
Table 1. Distribution of characteristics of subjects at baseline by parity

\begin{tabular}{|c|c|c|}
\hline Characteristics & $\begin{array}{c}\text { Nulliparous } \\
\text { women } \\
\left(\begin{array}{c}N=16589) \\
n(\%)\end{array}\right.\end{array}$ & $\begin{array}{c}\text { Parous women } \\
(\mathbf{N}=108848) \\
n(\%)\end{array}$ \\
\hline \multicolumn{3}{|l|}{ Age (years) ${ }^{a}$} \\
\hline$<55$ & $2273(13.7)$ & $8462(7.8)$ \\
\hline $55-<60$ & 4510 (27.2) & $27277(25.1)$ \\
\hline $60-<65$ & 4294 (25.9) & $33008(30.3)$ \\
\hline$\geqslant 65$ & $5512(33.2)$ & $40101(36.8)$ \\
\hline
\end{tabular}

\begin{tabular}{l|r|r|}
\hline \multicolumn{3}{|l|}{ Race/Ethnicity } \\
\hline Non-hispanic white & $15176(91.5)$ & $99205(90.7)$ \\
Non-hispanic black & $653(3.9)$ & $5336(4.9)$ \\
Hispanic & $229(1.4)$ & $1719(1.6)$ \\
Other & $395(2.4)$ & $2138(2.0)$ \\
Missing & $136(0.8)$ & $948(0.9)$
\end{tabular}

\begin{tabular}{|c|c|c|}
\hline \multicolumn{3}{|l|}{ Education } \\
\hline Less than high school & $2823(17.0)$ & $27280(25.1)$ \\
\hline High school & $1609(9.7)$ & $16750(15.4)$ \\
\hline Some college/vocational & $3570(21.5)$ & $30893(28.4)$ \\
\hline College graduate or more & $8285(49.9)$ & $31718(29.1)$ \\
\hline Missing & $302(1.8)$ & $2207(2.0)$ \\
\hline
\end{tabular}

\begin{tabular}{|l|c|c|}
\hline \multicolumn{3}{|l|}{ BMI (kg m $\left.{ }^{-2}\right)^{\mathbf{a}}$} \\
\hline$<25$ & $7842(47.3)$ & $47383(43.5)$ \\
$25.0-29.9$ & $4804(29.0)$ & $35077(32.2)$ \\
$\geqslant 30.0$ & $3517(21.2)$ & $23963(22.0)$ \\
Missing & $426(2.6)$ & $2425(2.3)$
\end{tabular}

\section{Marital status}

\begin{tabular}{|l|c|c|}
\hline Married or living as married & $4665(28.1)$ & $57844(53.1)$ \\
Widowed & $2092(12.6)$ & $24249(22.3)$ \\
Divorced & $2597(15.7)$ & $24059(22.1)$ \\
Separated & $109(0.7)$ & $1563(1.4)$ \\
Never married & $7037(42.4)$ & $549(0.5)$ \\
Missing & $89(0.5)$ & $584(0.5)$
\end{tabular}

\section{Duration of use of oral contraceptives}

\begin{tabular}{|l|c|c|}
\hline Never users or $<1$ year & $11932(71.9)$ & $64061(58.9)$ \\
$1-9$ years & $3290(19.8)$ & $32730(30.1)$ \\
$\geqslant 10$ years & $1318(8.0)$ & $11520(10.6)$ \\
Missing & $49(0.3)$ & $537(0.5)$
\end{tabular}

\begin{tabular}{|c|c|c|}
\hline \multicolumn{3}{|c|}{ Duration of hormone therapy use } \\
\hline Never users & 9003 (54.3) & $52336(48.1)$ \\
\hline$<10$ years & $5466(33.0)$ & 38685 (35.5) \\
\hline$\geqslant 10$ years & $2064(12.4)$ & $17413(16.0)$ \\
\hline Missing & $56(0.3)$ & $414(0.4)$ \\
\hline
\end{tabular}

\begin{tabular}{|l|c|c|}
\hline \multicolumn{3}{|l|}{ Age at menarche } \\
\hline Early & $7505(45.2)$ & $44409(40.8)$ \\
Middle & $7278(43.9)$ & $49433(45.4)$ \\
Late & $1765(10.6)$ & $14818(13.6)$ \\
Missing & $41(0.3)$ & $188(0.2)$ \\
\hline
\end{tabular}

\begin{tabular}{|c|c|c|}
\hline \multicolumn{3}{|c|}{ Age at last menstrual cycle (years) } \\
\hline $\begin{array}{l}\leqslant 44 \\
45-49 \\
50-54 \\
\geqslant 55\end{array}$ & $\begin{array}{l}4027(24.2) \\
4599(27.6) \\
6772(40.7) \\
1191(7.2)\end{array}$ & $\begin{array}{l}30996(28.3) \\
25583(23.4) \\
41446(37.9) \\
10823(9.9)\end{array}$ \\
\hline \multicolumn{3}{|c|}{ Hysterectomy ${ }^{a}$} \\
\hline $\begin{array}{l}\text { No } \\
\text { Yes } \\
\text { Missing }\end{array}$ & $\begin{array}{c}14123(85.1) \\
2410(14.5) \\
56(0,3)\end{array}$ & $\begin{array}{c}77921(71.6) \\
30569(28.1) \\
358(0.3)\end{array}$ \\
\hline
\end{tabular}

\section{Table 1. (Continued)}

\begin{tabular}{|c|c|c|}
\hline Characteristics & $\begin{array}{c}\text { Nulliparous } \\
\text { women } \\
\left(\begin{array}{c}N=16589) \\
n(\%)\end{array}\right.\end{array}$ & $\begin{array}{c}\text { Parous women } \\
(\mathbf{N}=108848) \\
n(\%)\end{array}$ \\
\hline \multicolumn{3}{|l|}{ Tubal ligation $^{\mathrm{b}}$} \\
\hline $\begin{array}{l}\text { No } \\
\text { Yes } \\
\text { Missing }\end{array}$ & $\begin{array}{c}2524(92.8) \\
174(6.4) \\
22(0.8)\end{array}$ & $\begin{array}{c}21084(76.7) \\
6305(23.0) \\
88(0.3)\end{array}$ \\
\hline \multicolumn{3}{|l|}{ Endometriosis $^{b}$} \\
\hline $\begin{array}{l}\text { No } \\
\text { Yes } \\
\text { Missing }\end{array}$ & $\begin{array}{c}2382(87.6) \\
227(8.3) \\
111(4.1)\end{array}$ & $\begin{array}{c}24895(90.6) \\
1502(5.5) \\
1080(3.9)\end{array}$ \\
\hline \multicolumn{3}{|c|}{ Miscarriages/abortions ${ }^{b}$} \\
\hline $\begin{array}{l}\text { No } \\
\text { One } \\
\text { Two or more } \\
\text { Missing }\end{array}$ & $\begin{array}{c}2250(82.7) \\
300(11.0) \\
168(6.2) \\
2(0.1)\end{array}$ & $\begin{array}{c}17593(64.0) \\
6383(23.2) \\
3463(12.6) \\
38(0.1)\end{array}$ \\
\hline \multicolumn{3}{|l|}{ Infertility ${ }^{b, c}$} \\
\hline $\begin{array}{l}\text { No } \\
\text { Yes } \\
\text { Missing }\end{array}$ & $\begin{array}{c}1917(70.5) \\
785(28.9) \\
18(0.7)\end{array}$ & $\begin{array}{c}24070(87.6) \\
3324(12.1) \\
83(0.3)\end{array}$ \\
\hline \multicolumn{3}{|c|}{ First degree family history of breast and/or ovarian cancer } \\
\hline $\begin{array}{l}\text { No } \\
\text { Yes } \\
\text { Missing }\end{array}$ & $\begin{array}{r}10429(62.9) \\
2891(17.4) \\
3269(19.7)\end{array}$ & $\begin{array}{l}77367(71.1) \\
19729(18.1) \\
11752(10.8)\end{array}$ \\
\hline \multicolumn{3}{|l|}{ Smoking status ${ }^{a}$} \\
\hline $\begin{array}{l}\text { Never } \\
\text { Former } \\
\text { Current } \\
\text { Missing }\end{array}$ & $\begin{array}{c}7676(46.3) \\
6344(38.2) \\
2238(13.5) \\
331(2.0)\end{array}$ & $\begin{array}{c}51083(46.9) \\
41830(38.4) \\
13847(12.7) \\
2088(1.9)\end{array}$ \\
\hline \multicolumn{3}{|c|}{ 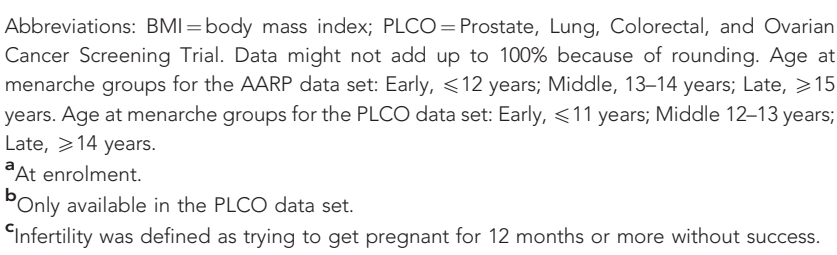 } \\
\hline
\end{tabular}

We further explored whether the relationship between BMI and parity differed by the number of births among parous women (Supplementary Table 1). Among the 108370 parous women with information on number of births, there were 11706 (10.8\%) with one birth, 31451 (29.0\%) with two births, 48397 (44.7\%) with three or four births, and 16816 (15.5\%) with five or more births. Five-hundred seventeen invasive ovarian cancer cases among parous women had information on the number of births. Of these, 75 (14.5\%) had one birth, 158 (30.6\%) had two births, 225 (43.5\%) had three to four births and 59 (11.4) had five or more births. Comparing nulliparous women with women with one, two, three to four or five or more births, there was no clear pattern of effect modification $(P$-heterogeneity $=0.05,0.63,0.14$, and 0.35 , respectively).

As HT use has been suggested to modify the association between BMI and ovarian cancer, we additionally stratified the BMI analyses by HT use (Table 4). Among never HT users, the association between BMI and ovarian cancer was stronger in nulliparous women compared with parous women, although the 


\begin{tabular}{|c|c|c|c|}
\hline Risk factor & Cases $(\mathbf{N}=623) n(\%)$ & $\mathrm{HR}^{\mathrm{a}}$ & $(95 \% \mathrm{Cl})^{a}$ \\
\hline \multicolumn{4}{|l|}{ Parity } \\
\hline $\begin{array}{l}\text { Nulliparous } \\
\text { Parous }\end{array}$ & $\begin{array}{r}95(16.1) \\
496(83.9)\end{array}$ & $\begin{array}{l}1.00 \\
0.79\end{array}$ & $\begin{array}{c}\text { ref. } \\
(0.63,0.98)\end{array}$ \\
\hline \multicolumn{4}{|c|}{ Number of births } \\
\hline $\begin{array}{l}\text { Nulliparous } \\
1 \\
2 \\
3-4 \\
\geqslant 5\end{array}$ & $\begin{array}{c}95(16.1) \\
71(12.1) \\
155(26.3) \\
216(36.7) \\
52(8.8)\end{array}$ & $\begin{array}{l}1.00 \\
1.09 \\
0.87 \\
0.75 \\
0.51\end{array}$ & $\begin{array}{c}\text { ref. } \\
(0.80,1.48) \\
(0.67,1.13) \\
(0.59,0.96) \\
(0.36,0.72)\end{array}$ \\
\hline & & & $P_{\text {trend }}<0.001$ \\
\hline \multicolumn{4}{|c|}{$\begin{array}{l}\text { Abbreviations: } \mathrm{Cl}=\text { confidence interval; } \mathrm{HR}=\text { hazard ratio; PLCO }=\text { Prostate, Lung, } \\
\text { Colorectal, and Ovarian Cancer Screening Trial. Numbers only for women with no-missing } \\
\text { values for the exposure of interest and corresponding adjusting variables. } \\
\text { a Adjusted for } \mathrm{BMI} \text { (continuous), duration of use of oral contraceptives (never or }<1 / 1-9 / \\
\geqslant 10 \text { years), duration of use of hormone therapy (Never/ }<10 / \geqslant 10 \text { years), first degree family } \\
\text { history of breast and/or ovarian cancer (no/yes/missing) and stratifying the baseline function } \\
\text { by study (PLCO vs AARP). }\end{array}$} \\
\hline
\end{tabular}

difference was not statistically significant $(P$-heterogeneity $=0.76)$. Among ever HT users, nulliparous women with BMI above $30 \mathrm{~kg} \mathrm{~m}^{-2}$ had a non-statistically significant higher risk of ovarian cancer compared with women with BMI $<25 \mathrm{~kg} \mathrm{~m}^{-2}$ (HR $=1.50$, 95\% CI: $0.57-3.92)$. This increased risk was not seen for parous women $(\mathrm{HR}=0.70,95 \% \mathrm{CI}: 0.44-1.11)(P$-heterogeneity $=0.08)$.

Finally, we did not observe a difference between histological subtypes of epithelial ovarian cancer (serous, mucinous, endometroid, clear cell, and other) and parity status (nulliparous $v s$ parous) $\left(\chi^{2}\right.$-test $P$-value: 0.13$)$ (Supplementary Table 2$)$.

\section{DISCUSSION}

We assessed whether the relationship between hormone-related factors and ovarian cancer risk differed between nulliparous and parous women using data from two large prospective cohorts. Overall, we did not observe significant differences in risk factor associations between nulliparous and parous women. We only found a suggestive difference of the associations between BMI and ovarian cancer risk in ever users of HT, whereby the estimated ovarian cancer risk associated with BMI was greater among nulliparous women than parous women. However, because of the number of tests performed, this finding could be due to chance. These data suggest that the impact of most factors on ovarian cancer risk is the same for nulliparous women as for parous women, even though ovarian cancer incidence is higher among nulliparous women.

We found a suggestive difference between never $v s$ current smokers and risk of ovarian cancer by parity. However, in a recent meta-analysis of 51 epidemiological studies, including the NIHAARP study and the PLCO trial, there was no difference in ovarian cancer risk between never and current smokers when stratified by parity (Collaborative Group on Epidemiological Studies of Ovarian Cancer et al, 2012). Given the small numbers of ovarian cancer cases who were current smokers in our study, this suggestive difference could just be chance.

Previously, it had been found that BMI significantly increased the risk of ovarian cancer by a 2.5-fold in nulliparous women, but not in parous women (Greer et al, 2006). We also observed that BMI increased the risk of ovarian cancer by nearly 1.5 -fold in nulliparous women, albeit non-significant, but not in parous women. However, in both studies the test of heterogeneity did not reach statically significance ( $P$-interaction $=0.06$ in (Greer et al, 2006 ) and $P$-interaction $=0.15$ in our study). A limitation of the study by Greer et al (2006) was the inclusion of pre- and postmenopausal women and the lack of information on HT use among postmenopausal women. It has been reported that BMI and HT may interact on the risk of ovarian cancer (Leitzmann et al, 2009; Collaborative Group on Epidemiological Studies of Ovarian Cancer, 2012). We were able to look at this interaction separately among nulliparous and parous women, and found some differences in the magnitude of the associations, although the number of cases in these subgroups was too small to reach firm conclusions. However, it may be worthwhile to assess this association in larger studies.

In a case-control study the use of OC did not reduce the risk of ovarian cancer in nulliparous women, but it was associated with a lower risk in parous women (Ness et al, 2001). We did not observe any qualitative difference in the risk estimates for OC use between nulliparous and parous women.

A previous prospective study based on 181 ovarian cancer cases found that the association between nulliparity and ovarian cancer was stronger among those with a first degree family history of breast or ovarian (Vachon et al, 2002). While first degree family history of breast or ovarian cancer was more strongly associated with ovarian cancer in nulliparous than in parous women in our study, neither association reached statistical significance and our estimates were lower than those found earlier (Vachon et al, 2002). The study by Vachon et al (2002) was also a prospective study of postmenopausal women with similar follow-up time, but our combined data set was larger (37377 vs 125437 ) and there were more incident epithelial ovarian cases (181 vs 623). However, there were a higher proportion of nulliparous women with missing information on family history than parous women in our study.

Our study has several limitations. Despite combining two large studies, the number of cases was small and may have precluded us from observing statistically significant associations. However, our sample size was larger than any other previous study. Given the low incidence of ovarian cancer, a small number of cases is a common problem of prospective studies of this disease. Another limitation was that we did not have fertility information in the NIH-AARP study, and, therefore, we could not adjust for this variable, which may be particularly important in the nulliparous group. About $60 \%$ of the nulliparous women were ever married (married, widowed, divorced, or separated) or living as married. As these women might have reproductive and hormonal characteristics different from nulliparous women who were never married or did not live as married, we conducted sensitivity analyses restricted to women who were ever married or living as married. However, the results were similar to those presented in our tables. For some factors that have been associated with ovarian cancer, such as tubal ligation, endometriosis or infertility, information was only available in the PLCO data set, and the number of ovarian cancer cases among nulliparous women was too small $(N=8)$ to determine the ovarian cancer risk associated with them. Finally, we did not have follow-up information regarding oophorectomy after enrolment and, therefore, we could not censor women who removed their ovaries after the beginning of the study. Our study has several notable strengths such as the prospective design with long followup, a larger number of nulliparous women compared with previous studies, and the comprehensive assessment of hormonal risk factors.

In summary, we did not observe significant differences in strengths of associations of known risk factors between among nulliparous and parous women. There was a suggestive interaction between BMI and parity in ever users of HT. Pooled analyses or larger studies are needed to provide more definitive and reliable evidence of this potential interaction. 
Table 3. Risk of invasive epithelial ovarian cancer in relation to hormone-related factors by parity

\begin{tabular}{|c|c|c|c|c|c|c|c|}
\hline \multirow[b]{2}{*}{ Risk factor } & \multicolumn{3}{|c|}{ Nulliparous women } & \multicolumn{3}{|c|}{ Parous women } & \multirow[b]{2}{*}{ P-heterogeneity ${ }^{c}$} \\
\hline & $\begin{array}{c}\text { Cases } \\
(\mathbf{N}=102) n(\%)\end{array}$ & $H R^{a}$ & $(95 \% \mathrm{Cl})^{\mathrm{a}}$ & $\begin{array}{c}\text { Cases } \\
(N=521) n(\%)\end{array}$ & $H R^{b}$ & $(95 \% \mathrm{Cl})^{\mathrm{b}}$ & \\
\hline Duration of use of $O C$ & & & & & & & 0.98 \\
\hline $\begin{array}{l}\text { Never users or }<1 \text { year } \\
1-9 \text { years } \\
\geqslant 10 \text { years }\end{array}$ & $\begin{array}{c}76(80.0) \\
15(15.8) \\
4(4.2)\end{array}$ & $\begin{array}{c}1.00 \\
0.78 \\
0.53 \\
P_{\text {trend }}=0.16\end{array}$ & $\begin{array}{c}\text { ref. } \\
(0.44,1.39) \\
(0.19,1.47)\end{array}$ & $\begin{array}{c}333(67.4) \\
133(26.9) \\
28(5.7)\end{array}$ & $\begin{array}{c}1.00 \\
0.81 \\
0.45 \\
P_{\text {trend }}<0.001\end{array}$ & $\begin{array}{c}\text { ref. } \\
(0.66,1.00) \\
(0.30,0.66)\end{array}$ & \\
\hline Duration of HT use & & & & & & & 0.18 \\
\hline $\begin{array}{l}\text { Never users } \\
<10 \text { years } \\
\geqslant 10 \text { years }\end{array}$ & $\begin{array}{l}55(57.9) \\
24(25.3) \\
16(16.8)\end{array}$ & $\begin{array}{c}1.00 \\
0.85 \\
1.46 \\
P_{\text {trend }}=0.41\end{array}$ & $\begin{array}{c}\text { ref. } \\
(0.52,1.40) \\
(0.83,2.58)\end{array}$ & $\begin{array}{l}195(39.5) \\
196(39.7) \\
103(20.9)\end{array}$ & $\begin{array}{c}1.00 \\
1.46 \\
1.61 \\
P_{\text {trend }}<0.001\end{array}$ & $\begin{array}{c}\text { ref. } \\
(1.19,1.79) \\
(1.27,2.06)\end{array}$ & \\
\hline Age at menarche & & & & & & & 0.24 \\
\hline $\begin{array}{l}\text { Early } \\
\text { Middle } \\
\text { Late }\end{array}$ & $\begin{array}{c}46(48.4) \\
45(47.4) \\
4(4.2)\end{array}$ & $\begin{array}{c}1.00 \\
1.10 \\
0.45 \\
P_{\text {trend }}=0.42\end{array}$ & $\begin{array}{c}\text { ref. } \\
(0.73,1.6)] \\
(0.16,1.25)\end{array}$ & $\begin{array}{r}201(40.7) \\
232(47.0) \\
61(12.4)\end{array}$ & $\begin{array}{c}1.00 \\
0.99 \\
0.85 \\
P_{\text {trend }}=0.38\end{array}$ & $\begin{array}{c}\text { ref. } \\
(0.82,1.21) \\
(0.63,1.14)\end{array}$ & \\
\hline Age at last menstrual cycle (years) & & & & & & & 0.48 \\
\hline $\begin{array}{l}\leqslant 44 \\
45-49 \\
50-54 \\
\geqslant 55\end{array}$ & $\begin{array}{c}24(25.3) \\
29(30.5) \\
34(35.8) \\
8(8.4)\end{array}$ & $\begin{array}{c}1.00 \\
1.13 \\
0.92 \\
1.24 \\
P_{\text {trend }}=0.96\end{array}$ & $\begin{array}{c}\text { ref. } \\
(0.65,1.94) \\
(0.54,1.56) \\
(0.55,2.78)\end{array}$ & $\begin{array}{r}137(27.7) \\
103(20.9) \\
202(40.9) \\
52(10.5)\end{array}$ & $\begin{array}{c}1.00 \\
0.95 \\
1.15 \\
1.08 \\
P_{\text {trend }}=0.23\end{array}$ & $\begin{array}{c}\text { ref. } \\
(0.73,1.23) \\
(0.92,1.44) \\
(0.78,1.50)\end{array}$ & \\
\hline Lifetime ovulatory cycles ${ }^{\text {d }}$ (LOC) & & & & & & & 0.50 \\
\hline $\begin{array}{l}\mathrm{Q} 4(>470) \\
\mathrm{Q} 3(>411 \text { and } \geqslant 470) \\
\mathrm{Q} 2(>330 \text { and } \leqslant 411) \\
\mathrm{Q} 1(\leqslant 330)\end{array}$ & $\begin{array}{c}37(39.0) \\
27(28.4) \\
25(26.3) \\
6(6.3)\end{array}$ & $\begin{array}{c}1.00 \\
1.18 \\
1.10 \\
0.74 \\
P_{\text {trend }}=0.90\end{array}$ & $\begin{array}{c}\text { ref. } \\
(0.72,1.96) \\
(0.65,1.88) \\
(0.29,1.86)\end{array}$ & $\begin{array}{l}150(30.4) \\
117(23.7) \\
118(23.9) \\
109(22.1)\end{array}$ & $\begin{array}{c}1.00 \\
0.81 \\
0.77 \\
0.76 \\
P_{\text {trend }}=0.05\end{array}$ & $\begin{array}{c}\text { ref. } \\
(0.63,1.03) \\
(0.60,1.00) \\
(0.58,1.01)\end{array}$ & \\
\hline $\begin{array}{l}\text { First degree family history of breast } \\
\text { and/or ovarian cancer }\end{array}$ & & & & & & & 0.60 \\
\hline $\begin{array}{l}\text { No } \\
\text { Yes }\end{array}$ & $\begin{array}{l}48(71.6) \\
19(28.4)\end{array}$ & $\begin{array}{l}1.00 \\
1.37\end{array}$ & $\begin{array}{c}\text { ref. } \\
(0.81,2.34)\end{array}$ & $\begin{array}{l}344(76.6) \\
105(23.4)\end{array}$ & $\begin{array}{l}1.00 \\
1.21\end{array}$ & $\begin{array}{c}\text { ref. } \\
(0.97,1.51)\end{array}$ & \\
\hline BMI $\left(\mathrm{kg} \mathrm{m}^{-2}\right)^{\mathbf{e}}$ & & & & & & & 0.15 \\
\hline $\begin{array}{l}<25 \\
25-29.9 \\
\geqslant 30\end{array}$ & $\begin{array}{l}39(41.1) \\
32(33.7) \\
24(25.3)\end{array}$ & $\begin{array}{c}1.00 \\
1.36 \\
1.48 \\
P_{\text {trend }}=0.32\end{array}$ & $\begin{array}{c}\text { ref. } \\
(0.79,2.36) \\
(0.61,3.58)\end{array}$ & $\begin{array}{l}237(48.0) \\
144(29.2) \\
113(22.9)\end{array}$ & $\begin{array}{c}1.00 \\
0.84 \\
1.03 \\
P_{\text {trend }}=0.71\end{array}$ & $\begin{array}{c}\text { ref. } \\
(0.66,1.07) \\
(0.69,1.53)\end{array}$ & \\
\hline Hysterectomy & & & & & & & 0.54 \\
\hline $\begin{array}{l}\text { No } \\
\text { Yes }\end{array}$ & $\begin{array}{l}82(86.3) \\
13(13.7)\end{array}$ & $\begin{array}{l}1.00 \\
0.83\end{array}$ & $\begin{array}{c}\text { ref. } \\
(0.45,1.53)\end{array}$ & $\begin{array}{l}346(70.0) \\
148(30.0)\end{array}$ & $\begin{array}{l}1.00 \\
1.00\end{array}$ & $\begin{array}{c}\text { ref. } \\
(0.82,1.23)\end{array}$ & \\
\hline Smoking status & & & & & & & 0.10 \\
\hline $\begin{array}{l}\text { Never } \\
\text { Former } \\
\text { Current } \\
\end{array}$ & $\begin{array}{l}43(45.7) \\
35(37.2) \\
16(17.0) \\
\end{array}$ & $\begin{array}{l}1.00 \\
0.99 \\
1.40 \\
\end{array}$ & $\begin{array}{c}\text { ref. } \\
(0.63,1.55) \\
(0.78,2.49) \\
\end{array}$ & $\begin{array}{c}253(52.0) \\
189(38.8) \\
45(9.2) \\
\end{array}$ & $\begin{array}{l}1.00 \\
0.93 \\
0.76 \\
\end{array}$ & $\begin{array}{c}\text { ref. } \\
(0.77,1.13) \\
(0.55,1.05) \\
\end{array}$ & \\
\hline $\begin{array}{l}\text { Abbreviations: BMI = body mass index; } \mathrm{Cl} \\
\text { exposure of interest and corresponding adj } \\
\text { the PLCO data set: Early, } \leqslant 11 \text { years; Mido } \\
{ }^{\text {a }} \text { Adjusted for BMI (continuous), duration of } \\
\text { of breast and/or ovarian cancer (no/yes/mi } \\
{ }^{b} \text { Adjusted for same variables as nulliparou } \\
{ }^{c} \text { Based on a likelihood-ratio test comparin } \\
\text { exposure of interested (coded in continuo } \\
{ }^{d} \text { Ovulatory cycles computed according to } \\
\text { (1995). The average cycle length was set to } \\
\text { AARP. Quartiles of lifetime ovulatory cycle } \\
{ }_{\text {A At enrolment. }}\end{array}$ & $\begin{array}{l}\text { ing variables. Age at me } \\
12-13 \text { years; Late, } \geqslant 14 \\
\text { e of oral contraceptives } \\
\text { g) and stratifying the } \\
\text { nalysis plus number of } \\
\text { model fitted to all wo } \\
\text { form) to a model witho } \\
\text { formula [(age at menof } \\
\text { days. All the other charc } \\
\text { ere defined based on }\end{array}$ & $\begin{array}{l}\text { narche groups for } \\
\text { ears. } \\
\text { (never or }<1 / 1-9 / \\
\text { aseline function } b \\
\text { ve births }(1 / 2 / 3-4 \\
\text { nen with variable } \\
t \text { the interaction } \\
\text { ause - age at me } \\
\text { cteristics were set } \\
\text { e distribution in }\end{array}$ & 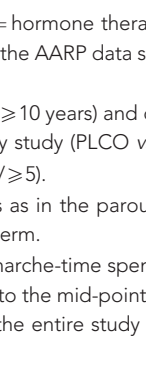 & $\begin{array}{l}\text { Early, } \leqslant 12 \text { years; Midd } \\
\text { uration of use of hormon } \\
\text { AARP). } \\
\text { analysis plus parity stat } \\
\text { pregnant-duration of } O \\
\text { f the interval of the corre } \\
\text { opulation. }\end{array}$ & $\begin{array}{l}\text { Ile, 13-14 years; Lat } \\
\text { us (yes/no) and an } \\
\text { Cuse)*365.25//ave } \\
\text { esponding variable }\end{array}$ & $\begin{array}{l}\text { for women with } \\
\text { te, } \geqslant 15 \text { years. Ag } \\
<10 / \geqslant 10 \text { years), } \\
\text { interaction term } \\
\text { rage cycle length } \\
\text {, separately for th }\end{array}$ & $\begin{array}{l}\text { no-missing values for the } \\
\text { first degree family history } \\
\text { of parity status time the } \\
\text {, as given in Cramer et al } \\
\text { he PLCO and for the NIH- }\end{array}$ \\
\hline
\end{tabular}


Table 4. Risk of invasive epithelial ovarian cancer in relation to BMI by HT use and parity

\begin{tabular}{|c|c|c|c|c|c|c|c|}
\hline & \multicolumn{3}{|c|}{ Nulliparous women } & \multicolumn{3}{|c|}{ Parous women } & \multirow[b]{2}{*}{ P-heterogeneity ${ }^{c}$} \\
\hline Stratum/risk factor & Cases $\boldsymbol{n}(\%)$ & $\mathrm{HR}^{\mathrm{a}}$ & $(95 \% \mathrm{Cl})^{a}$ & Cases $\boldsymbol{n}(\%)$ & $\mathrm{HR}^{\mathrm{b}}$ & $(95 \% \mathrm{Cl})^{\mathrm{b}}$ & \\
\hline \multicolumn{8}{|l|}{ Never users of HT } \\
\hline $\mathrm{BMI}\left(\mathrm{kg} \mathrm{m}^{-2}\right)$ & & & & & & & 0.76 \\
\hline $\begin{array}{l}<25 \\
25-29.9 \\
\geqslant 30\end{array}$ & $\begin{array}{l}20(36.4) \\
21(38.2) \\
14(25.5)\end{array}$ & $\begin{array}{l}1.00 \\
1.90 \\
2.10\end{array}$ & $\begin{array}{c}\text { ref. } \\
(0.86,4.19) \\
(0.53,8.27) \\
P_{\text {trend }}=0.20\end{array}$ & $\begin{array}{l}70(35.9) \\
59(30.3) \\
66(33.9)\end{array}$ & $\begin{array}{l}1.00 \\
1.10 \\
1.83\end{array}$ & $\begin{array}{c}\text { ref. } \\
(0.73,1.66) \\
(0.95,3.52) \\
P_{\text {trend }}=0.11\end{array}$ & \\
\hline \multicolumn{8}{|l|}{ Ever users of HT } \\
\hline BMI $\left(\mathrm{kg} \mathrm{m}^{-2}\right)$ & & & & & & & 0.08 \\
\hline $\begin{array}{l}<25 \\
25-29.9 \\
\geqslant 30\end{array}$ & $\begin{array}{l}19(47.5) \\
11(27.5) \\
10(25.0)\end{array}$ & $\begin{array}{l}1.00 \\
1.01 \\
1.50\end{array}$ & $\begin{array}{c}\text { ref. } \\
(0.47,2.18) \\
(0.57,3.92) \\
P_{\text {trend }}=0.548 \\
\end{array}$ & $\begin{array}{r}167(55.9) \\
85(28.4) \\
47(15.7)\end{array}$ & $\begin{array}{l}1.00 \\
0.74 \\
0.70\end{array}$ & $\begin{array}{c}\text { ref. } \\
(0.55,0.99) \\
(0.44,1.11) \\
P_{\text {trend }}=0.05 \\
\end{array}$ & \\
\hline 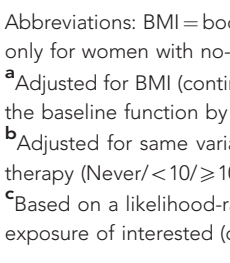 & $\begin{array}{l}\text { lass index; } \mathrm{Cl}=\mathrm{c} \\
\text { ing values for the } \\
\text { us), duration of us } \\
\text { dy (PLCO vs AARF } \\
\text { s as nulliparous a } \\
\text { ars). } \\
\text { test comparing a } \\
\text { d in continuous } f\end{array}$ & $\begin{array}{l}\text { ce inter } \\
\text { sure of ir } \\
\text { al contra } \\
\text { plus nu } \\
\text { I fitted t }\end{array}$ & $\begin{array}{l}\text { hazard ratio; } \mathrm{HT}= \\
\text { id corresponding } \\
\text { (never or }<1 / 1-9 / \\
\text { live births }(1 / 2 / 3-4 \\
\text { nen with variables }\end{array}$ & $\begin{array}{l}\text { ne therapy; PLCC } \\
\text { g variables. } \\
\text { ars), first degree } \\
\text { age at first birth } \\
\text { e parous analysis }\end{array}$ & $\begin{array}{l}\text { tate, Lun } \\
\text { istory of } \\
\text {-19/20-2 } \\
\text { arity statu }\end{array}$ & $\begin{array}{l}\text { orectal, and Ovar } \\
\text { and/or ovarian c } \\
29 / 30-34 / \geqslant 35 \text { yec } \\
\text { (no) and an interc }\end{array}$ & $\begin{array}{l}\text { er Screening Trial. Numbers } \\
\text { s/yes/missing) and stratifying } \\
\text { duration of use of hormone } \\
\text { rm of parity status times the }\end{array}$ \\
\hline
\end{tabular}

\section{ACKNOWLEDGEMENTS}

This research was supported by the Intramural Research Program of the National Cancer Institute and by contracts from the Division of Cancer Prevention, National Cancer Institute, NIH, DHHS. PLCO: We thank the Screening Center investigators and staff of the Prostate, Lung, Colorectal, and Ovarian (PLCO) Cancer Screening Trial, Mr Tom Riley and staff, Information Management Services, Inc., Ms Barbara O'Brien and staff, Westat, Inc. Most importantly, we acknowledge the PLCO study participants for their contributions to making this study possible. NIH-AARP: We are also indebted to the participants in the NIH-AARP Diet and Health Study for their outstanding cooperation. We also thank Sigurd Hermansen and Kerry Grace Morrissey from Westat for study outcomes ascertainment and management and Leslie Carroll at Information Management Services for data support and analysis. Cancer incidence data from the Atlanta metropolitan area were collected by the Georgia Center for Cancer Statistics, Department of Epidemiology, Rollins School of Public Health, Emory University, Atlanta, Georgia. Cancer incidence data from California were collected by the California Cancer Registry, California Department of Public Health's Cancer Surveillance and Research Branch, Sacramento, California. Cancer incidence data from the Detroit metropolitan area were collected by the Michigan Cancer Surveillance Program, Community Health Administration, Lansing, Michigan. The Florida cancer incidence data used in this report were collected by the Florida Cancer Data System (Miami, Florida) under contract with the Florida Department of Health, Tallahassee, Florida. The views expressed herein are solely those of the authors and do not necessarily reflect those of the FCDC or FDOH. Cancer incidence data from Louisiana were collected by the Louisiana Tumor Registry, Louisiana State University Health Sciences Center School of Public Health, New Orleans, Louisiana. Cancer incidence data from New Jersey were collected by the New Jersey State Cancer Registry, Cancer Epidemiology Services, New Jersey State Department of Health, Trenton, New Jersey. Cancer incidence data from North Carolina were collected by the North Carolina Central Cancer Registry, Raleigh, North Carolina. Cancer incidence data from Pennsylvania were supplied by the Division of Health Statistics and Research, Pennsylvania Department of Health, Harrisburg, Pennsylvania. The Pennsylvania Department of Health specifically disclaims responsibility for any analyses, interpretations or conclusions. Cancer incidence data from Arizona were collected by the Arizona Cancer Registry, Division of Public Health Services, Arizona Department of Health Services, Phoenix, Arizona. Cancer incidence data from Texas were collected by the Texas Cancer Registry, Cancer Epidemiology and Surveillance Branch, Texas Department of State Health Services, Austin, Texas. Cancer incidence data from Nevada were collected by the Nevada Central Cancer Registry, State Health Division, State of Nevada Department of Health and Human Services, Las Vegas, Nevada.

\section{CONFLICT OF INTEREST}

The authors declare no conflict of interest.

\section{REFERENCES}

Adami HO, Hsieh CC, Lambe M, Trichopoulos D, Leon D, Persson I, Ekbom A, Janson PO (1994) Parity, age at first childbirth, and risk of ovarian cancer. Lancet 344(8932): 1250-1254.

Collaborative Group on Epidemiological Studies of Ovarian Cancer (2012) Ovarian cancer and body size: individual participant meta-analysis including 25,157 women with ovarian cancer from 47 epidemiological studies. PLoS Med 9(4): e1001200.

Collaborative Group on Epidemiological Studies of Ovarian CancerBeral V, Gaitskell K, Hermon C, Moser K, Reeves G, Peto R (2012) Ovarian cancer and smoking: individual participant meta-analysis including 28,114 women with ovarian cancer from 51 epidemiological studies. Lancet Oncol 13(9): 946-956.

Cramer DW, Xu H, Harlow BL (1995) Does 'incessant' ovulation increase risk for early menopause? Am J Obstet Gynecol 172(2, Part 1): 568-573. 
Fritz AG, Percy C, Jack A, Shanmugarathan K, Sobin L, Parkin DM, Whelan S (2000) International Classification of Diseases for Oncology, ICD-O. World Health Organization: Geneva, Switzerland.

George N (2011) Determinants of lifetime ovulatory cycles and risk of ovarian cancer. Masters of Public Health Masters of Public Health, The George Washington University.

Grambsch PM, Therneau TM (1994) Proportional hazards tests and diagnostics based on weighted residuals. Biometrika 81(3): 515-526.

Greer JB, Modugno F, Ness RB, Allen GO (2006) Anthropometry and the risk of epithelial ovarian cancer. Cancer 106(10): 2247-2257.

Hankinson SE, Danforth KN (2006) Ovarian cancer. In Cancer Epidemiology and Prevention, Schottenfeld D, Fraumeni Jr JF (eds) 3 edn. Oxford University Press, Inc.: New York, NY, USA.

Leitzmann MF, Koebnick C, Danforth KN, Brinton LA, Moore SC, Hollenbeck AR, Schatzkin A, Lacey Jr JV (2009) Body mass index and risk of ovarian cancer. Cancer 115(4): 812-822.

Michaud D, Midthune D, Hermansen S, Leitzmann M, Harlan LC, Kipnis V, Schatzkin A (2005) Comparison of cancer registry case ascertainment with SEER estimates and self-reporting in a subset of the NIH-AARP Diet and Health Study. J Registry Manage 32(2): 70-75.

Modugno F, Ness RB, Wheeler JE (2001) Reproductive risk factors for epithelial ovarian cancer according to histologic type and invasiveness. Ann Epidemiol 11(8): 568-574.

Moorman PG, Calingaert B, Palmieri RT, Iversen ES, Bentley RC, Halabi S, Berchuck A, Schildkraut JM (2008) Hormonal risk factors for ovarian cancer in premenopausal and postmenopausal women. Am J Epidemiol 167(9): 1059-1069.

Ness RB, Ann Grisso J, Klapper J, Schlesselman JJ, Silberzweig S, Vergona R, Morgan M, Wheeler JE. and the SHARE Study Group (2000) Risk of ovarian cancer in relation to estrogen and progestin dose and use characteristics of oral contraceptives. Am J Epidemiol 152(3): 233-241.

Ness RB, Grisso JA, Vergona R, Klapper J, Morgan M, Wheeler JE (2001) Oral contraceptives, other methods of contraception, and risk reduction for ovarian cancer. Epidemiology 12(3): 307-312.

Olsen CM, Nagle C, Whiteman DC, Ness R, Pearce CL, Pike MC, Rossing MA, Terry K, Wu A, Risch H, Yu H, Doherty JA, Chang-Claude J, Hein R, Nickels S, Wang-Gohrke S, Goodman M, Carney ME, Matsuno RK, Lurie G, Moysich K, Kjaer SK, Jensen A, Hogdall E, Goode E, Fridley BL, Vierkant RA, Larson MC, Schildkraut J, Hoyo C, Moorman P, Weber RP, Cramer D, Vitonis AF, Bandera EV, Olsen S, Rodriguez-Rodriguez L,
King M, Brinton LA, Yang H, Garcia-Closas M, Lissowska J, Anton-Culver H, Ziogas A, Gayther SA, Ramus SJ, Menon U, Gentry-Maharaj A, Webb PM (2013) Obesity and risk of ovarian cancer subtypes: evidence from the Ovarian Cancer Association Consortium. Endocr Relat Cancer 20(2): 251-262.

Prorok PC, Andriole GL, Bresalier RS, Buys SS, Chia D, Crawford ED, Fogel R, Gelmann EP, Gilbert F, Hasson MA, Hayes RB, Johnson CC, Mandel JS, Oberman A, O'Brien B, Oken MM, Rafla S, Reding D, Rutt W, Weissfeld JL, Yokochi L, Gohagan JK (2000) Design of the Prostate, Lung, Colorectal and Ovarian (PLCO) Cancer Screening Trial. Controll Clin Trial 21(6 Suppl): 273S-309S.

Schatzkin A, Subar AF, Thompson FE, Harlan LC, Tangrea J, Hollenbeck AR, Hurwitz PE, Coyle L, Schussler N, Michaud DS, Freedman LS, Brown CC, Midthune D, Kipnis V (2001) Design and serendipity in establishing a large cohort with wide dietary intake distributions: the National Institutes of Health-American Association of Retired Persons Diet and Health Study. Am J Epidemiol 154(12): 1119-1125.

Schonfeld SJ, Pfeiffer RM, Lacey JV, Berrington de González A, Doody MM, Greenlee RT, Park Y, Schairer C, Schatzkin A, Sigurdson AJ, Hartge P, Visvanathan K (2011) Hormone-related risk factors and postmenopausal breast cancer among nulliparous versus parous women: an aggregated study. Am J Epidemiol 173(5): 509-517.

Tung K-H, Wilkens LR, Wu AH, McDuffie K, Nomura AMY, Kolonel LN, Terada KY, Goodman MT (2005) Effect of anovulation factors on pre- and postmenopausal ovarian cancer risk: revisiting the incessant ovulation hypothesis. Am J Epidemiol 161(4): 321-329.

Vachon CM, Mink PJ, Janney CA, Sellers TA, Cerhan JR, Hartmann L, Folsom AR (2002) Association of parity and ovarian cancer risk by family history of breast or ovarian cancer in a population-based study of postmenopausal women. Epidemiology 13(1): 66-71.

Whittemore AS, Harris R, Itnyre J (1992) Characteristics relating to ovarian cancer risk: collaborative analysis of 12 US case-control studies. II. Invasive epithelial ovarian cancers in white women. Collaborative Ovarian Cancer Group. Am J Epidemiol 136(10): 1184-1203.

This work is published under the standard license to publish agreement. After 12 months the work will become freely available and the license terms will switch to a Creative Commons AttributionNonCommercial-Share Alike 3.0 Unported License.

Supplementary Information accompanies this paper on British Journal of Cancer website (http://www.nature.com/bjc) 